\title{
Survey of Non-Prescribed Use of Antibiotics in Respiratory Tract Infections and Role of Community Pharmacists to Enlighten the Society
}

Zehra Ashraf*, Ranaa Amjad, Esha Idrees, Tuba Babar, Shanza Sultan and Sualiha Shafaq

Jinnah University for Women, Karachi, Pakistan

\begin{abstract}
Objectives: The goal of this study was to identify the conditions in which patients self-administer antibiotics frequently. This survey based study is also aimed to reduce unnecessary self-medication particularly antibiotics among the large section of people and also to highlight the role of the community pharmacist to curb this menace.

Design: This report is based on a survey conducted at different parts of Karachi.

Main outcome measures: Self-medications of Antibiotic for cold, respiratory tract infections

Result and discussion: This community based survey was aimed to study the non-prescribed use of antibiotics in Karachi (Pakistan). The study showed that the self-medication of antibiotics is common in Upper Respiratory Tract Infections, which are generally caused by viruses. According to the survey reports more than $70 \%$ of antibiotics are purchased privately without a prescription due to many reasons. It is the prime role of community pharmacy to aware the public by different ways which includes awareness programs through print and electronic media, arranging seminars, walks, workshops to promote health related information to general public.
\end{abstract}

Keywords: Respiratory tract infections; Viral infections; Cold; Flu; Community pharmacy

\section{Introduction}

Respiratory tract infections are caused by viruses generally considered to be the airway above the glottis or vocal cords which includes the nose, throat, pharynx, larynx, and bronchi. Respiratory tract infection is the most common illness in many people [1]

Increasing rates of self-medicated antibiotics in viral infections like cold, flu, upper respiratory tract infections (URI's) have motivated the researchers and pharmacist on this public health problem [2].

According to the survey reports more than $70 \%$ of antibiotics are purchased privately without a prescription from pharmacies.

The condition in Pakistan is getting worst because the frequent use of antibiotics without physician's guidance is due to the ignorance about the side effects of drugs; repeated use of once prescribed medicines without fresh consultations has become a regular feature [3]. Medical stores normally oblige those who come to purchase medicines without any prescription only to enhance their profits ignoring laws of the land [4]. Another reason for buying medicines sans prescription is the exorbitant fee of good medical practitioners which compels buyers to purchase medicines on its own [5]. They cannot afford to consult doctors again and again. Similarly some of the patients are dissatisfied with medical practitioners so they prefer shortcuts [6]. Self-medication has also been noted particularly for colds and upper respiratory tract symptoms, which are self-limiting and commonly caused by viruses. Reducing unnecessary use of non-prescribing antibiotics in viral infections (colds, URIs, and bronchitis) [7].

The literature review also shows the irrational use of antibiotics in Respiratory tract infections is common in the world. Some studies also showed the irrational increase of antibiotics used by the people without bothering to consult their physicians and pharmacists [8]. One of the studies also showed that many of the parents request pediatricians to prescribe antibiotics for their children in order to get early relief in viral upper respiratory tract infections [9].
The goal of this study was to identify the conditions in which patients himself use antibiotics most frequently, whereas antibiotics have slightly irrational or non- beneficial for viral infections. This survey based study is also aimed to reduce unnecessary self-medication particularly antibiotics among the large section of people and also to highlight role of community pharmacists to curb this menace [10].

\section{Methods}

\section{Place of study}

The study site was Karachi highly populated city and largest city in the Muslim world, the capital of economic provision of Pakistan. Karachi is known as city of lights.

\section{Pattern of study}

A survey has been conducted to ascertain the quantum of selfmedication especially the use of antibiotics in viral diseases. For this purpose, a questionnaire was designed to conduct fresh survey from different parts of Karachi (Pakistan). Our sample size was 100. It was distributed among various segments of society including $31 \%$ professionals, $40 \%$ non-professionals and house wives, $29 \%$ students.

The questionnaire was based on MCQs asking the people to give their fair opinion about self-medication pointing out the reasons of taking non prescribed medicines and also state the types of antibiotics being used by them. Karachi is known as city of lights. Some of the

*Corresponding authors: Zehra Ashraf, Jinnah University for Women, Karachi, Pakistan, Tel: 00923002621917; E-mail: dr.zehra.ashraf@gmail.com

Mahrukh khuseed, Jinnah University for Women, Karachi, Pakistan

Received September 25, 2015; Accepted November 27, 2015; Published December 04, 2015

Citation: Ashraf Z, Amjad R, Idrees E, Babar T, Sultan S, et al. (2016) Survey of Non-Prescribed Use of Antibiotics in Respiratory Tract Infections and Role of Community Pharmacists to Enlighten the Society. J Bioequiv Availab 8: 006-007. doi:10.4172/jbb. 1000258

Copyright: ( 2016 Ashraf Z, et al. This is an open-access article distributed under the terms of the Creative Commons Attribution License, which permits unrestricted use, distribution, and reproduction in any medium, provided the original author and source are credited. 
questions asked by us included (a)-What are the common diseases you self-medicate yourself for? (b) What do you prefer for yourself or family if you suffer the same disease (nausea, diarrhea, flu, fever, cough) as last week/time you visited physician? (c) For how long you take non prescribe antibiotics for a period? (d) In what kind of symptoms you taken antibiotics without prescriptions?? (e) In your opinion what is the 1st line of treatment??

\section{Result}

Our survey was divided into three different categories i.e. Students, Professionals and Non-professionals (mothers and housewives,) result concluded that $16 \%$ students, $18 \%$ professionals and $40 \%$ nonprofessionals prefer self-medication including antibiotics and $13 \%$ students and $13 \%$ professionals are not using antibiotics without consultants advice shown in Figure 1. The commonly used selfmedicated antibiotics are 30\% Augmentin, 40\% Cefixime, $4 \%$ Kalarcid is shown in Figure 2. In students $9 \%$ use self-medication due to lack of time and $7 \%$ go to medical stores. In professionals $12 \%$ selfmedication from past experiences, $3 \%$ from medical stores and $4 \%$ use themselves at home. In non- professionals $30 \%$ use antibiotics at home, $5 \%$ at medical stores and $15 \%$ use from past experiences graph shown in Figure 3. As far as numbers of days are concerned patients are using antibiotics from the period of 3,5 and 7 days as shown in Figure 4 . Causes to use self-medication of antibiotics in respiratory

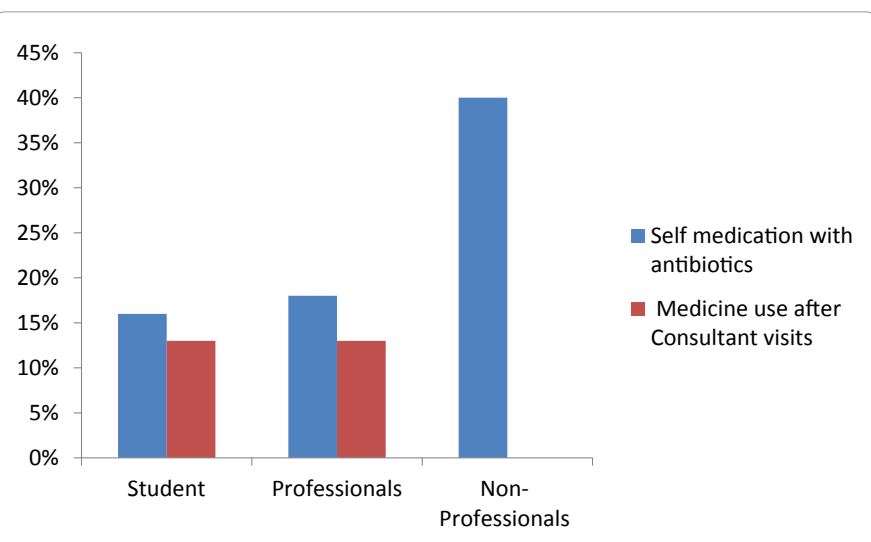

Figure 1: Self-Medication of antibiotics.

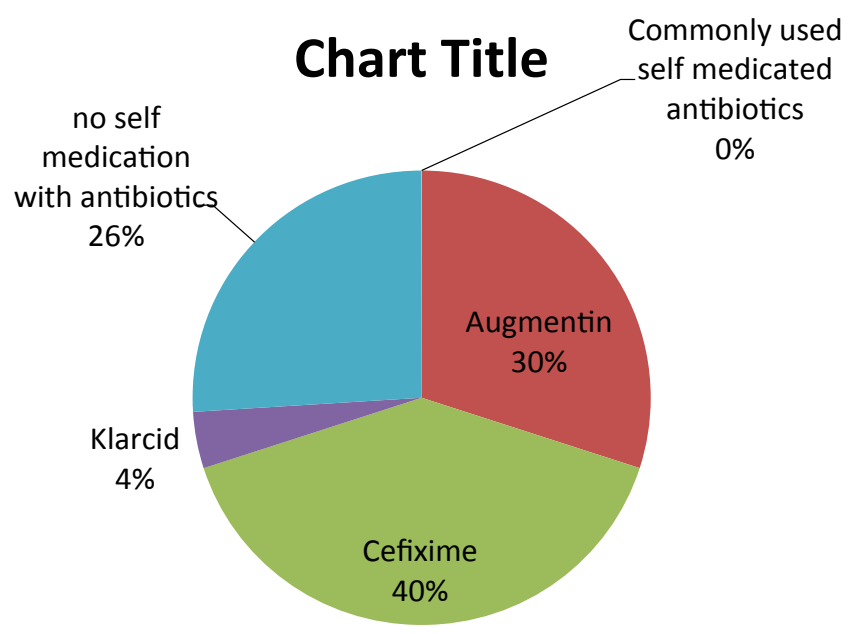

Figure 2: Commonly self-medicated antibiotics.

\section{Chart Title}

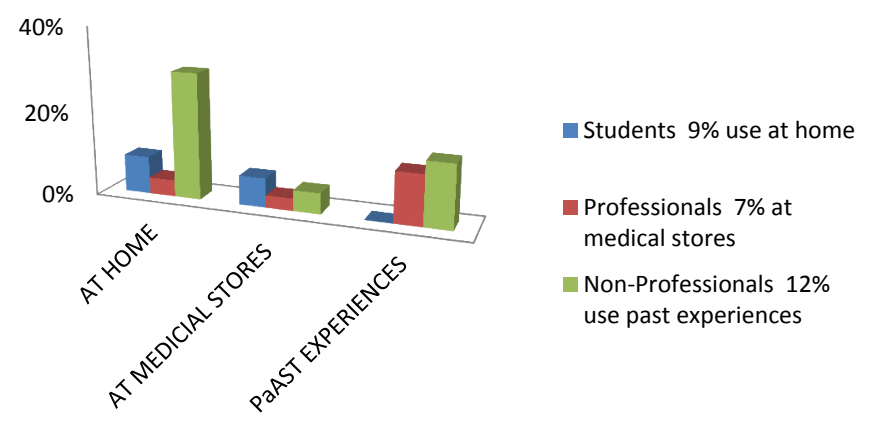

Figure 3: Sources to use self-medications.

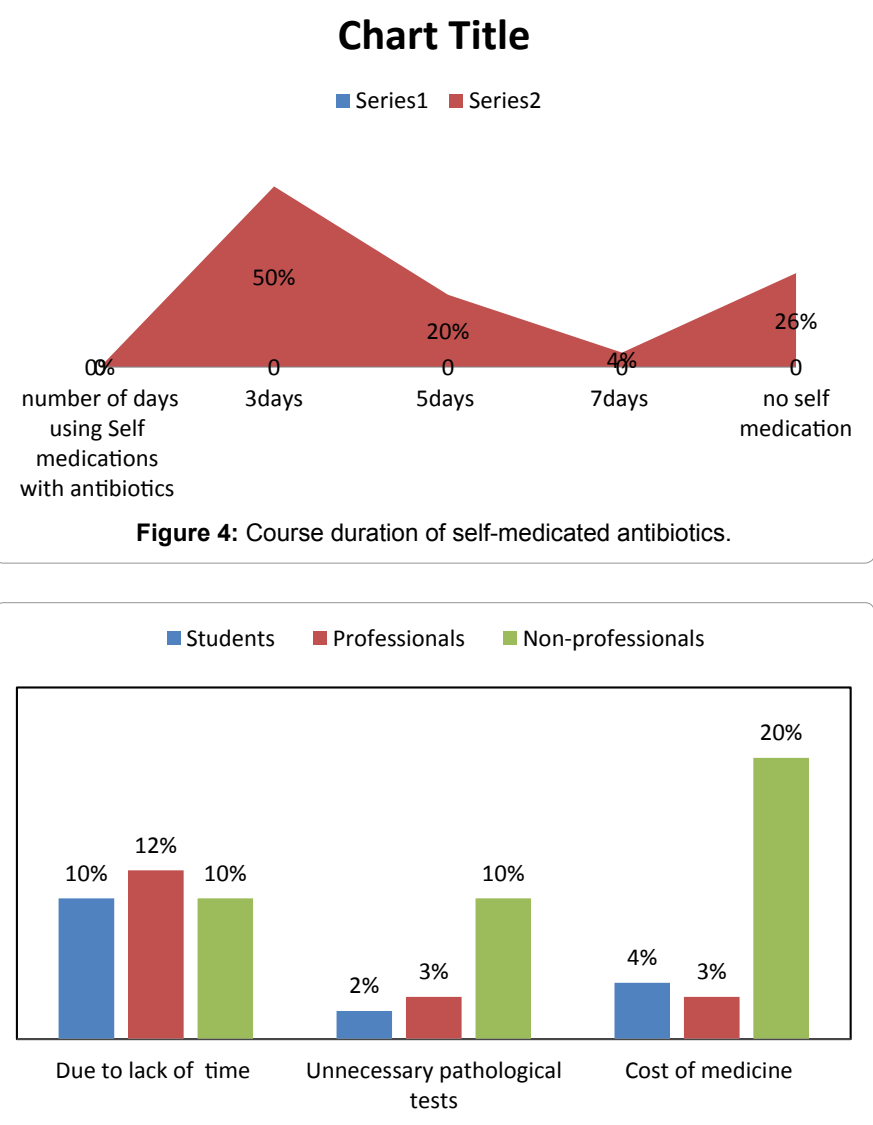

Figure 5: Reasons to do self-medication.

tract infections are due to cost of physicians, unnecessary pathological tests and high cost of medicines. This is shown in Figure 5.

\section{Discussion}

According to survey reports more than $70 \%$ of antibiotics are purchased privately without a prescription due to many reasons which are discussed below in details.

This community based survey was aimed to study the nonprescribed antibiotics used in Karachi (Pakistan). The study showed that the self-medication of antibiotics is common in Respiratory Tract Infection which is generally caused by viruses. Literature reviews also 
Citation: Ashraf Z, Amjad R, Idrees E, Babar T, Sultan S, et al. (2016) Survey of Non-Prescribed Use of Antibiotics in Respiratory Tract Infections and Role of Community Pharmacists to Enlighten the Society. J Bioequiv Availab 8: 006-007. doi:10.4172/jbb.1000258

showed that this practice is very common in developed and under developed countries. Our result indicated that the most common use of non-prescribed antibiotics is in acute respiratory tract infections including flu, cold and diarrhea [11]. In this regard people belong to various segments opened their mind by stating that self-medication is not always dangerous. It is their perception that they know the antibiotics they normally use. One of the most common practice is that they avoid to visit doctors due to many a reason including exorbitant fee of qualified doctors, heavy rush of patients consuming a lot of time, unnecessary pathological tests advised by doctors. So they prefer self-medication instead of visiting qualified doctors even they seek medicines from medical stores. Unfortunately in Pakistan qualified pharmacists are not available [12]. It is the prime role of community pharmacy to aware the public by different ways to arrange awareness programs through print and electronic media, arranging seminars, walks, workshops to promote health related information to general public [13]. Community pharmacist is basically the health professionals and they educate patients by counseling at the time of dispensing drugs. This is high time to save our primary public health and highlight the role of Pharmacists in under developed countries and make strategies to decline the trend of self-medications [14].

\section{References}

1. Norris $P$ (2007) Interventions to improve antimicrobial use: evidence from ICIUM 2004. Geneva: World Health Organization.

2. McNulty CA, Boyle P, Nichols T, Clappison DP, Davey $P$ (2006) Antimicrobial drugs in the home, United Kingdom. Emerg Infect Dis 12: 1523-1526.

3. Friedman JF, Lee GM, Kleinman KP, Finkelstein JA (2003) Acute care and antibiotic seeking for upper respiratory tract infections for children in day care: parental knowledge and day care center policies. Arch Pediatr Adolesc Med 157: $369-374$
4. Belongia EA, Naimi TS, Gale CM, Besser RE (2002) Antibiotic use and upper respiratory infections: a survey of knowledge, attitudes, and experience in Wisconsin and Minnesota. Prev Med 34: 346-352.

5. Larsson M, Kronvall G, Chuc NT, Karlsson I, Lager F, et al. (2000) Antibiotic medication and bacterial resistance to antibiotics: a survey of children in a Vietnamese community. Trop Med Int Health 5: 711-721.

6. Okumura J, Wakai S, Umenai T (2002) Drug utilisation and self-medication in rural communities in Vietnam. Soc Sci Med 54: 1875-1886.

7. Belongia EA, Naimi TS, Gale CM, Besser RE (2002) Antibiotic use and upper respiratory infections: a survey of knowledge, attitudes, and experience in Wisconsin and Minnesota. Prev Med 34: 346-352.

8. Batjargal J, Surenchimeg B, Solongo A, Tstetsgee P, Baljimaa B, et al. (2000) Survey on care practice for young children in Mongolia. Ulaanbaatar: Ministry of Health.

9. Ochirbat T, Ali M, Pagbajab N, Erkhembaatar LO, Budbazar E, et al. (2008) Assessment of hepatitis $B$ vaccine-induced seroprotection among children 5-10 years old in Ulaanbaatar, Mongolia. Biosci Trends 2: 68-74.

10. Berzanskyte A, Valinteliene R, Haaijer-Ruskamp FM, Gurevicius R, Grigoryan $L$ (2006) Self-medication with antibiotics in Lithuania. Int J Occup Med Environ Health 19: 246-253.

11. Suleman S, Ketsela A, Mekonnen Z (2009) Assessment of self-medication practices in Assendabo town, Jimma zone, southwestern Ethiopia. Res Social Adm Pharm 5: 76-81.

12. Guidelines for ATC classification and DDD assignment 2010. Oslo: WHO Collaborating Center for Drug Statistics Methodology; 2001.

13. Munkhdelger $C$ (2004) Survey of medicine prices, availability, affordability and price components in Mongolia. Ulaanbaatar: Ministry of Health, Department of Pharmaceutical and Health Devices.

14. Nyazema N, Viberg N, Khoza S, Vyas S, Kumaranayake L, et al. (2007) Low sale of antibiotics without prescription: a cross-sectional study in Zimbabwean private pharmacies. J Antimicrob Chemother 59: 718-726. 